慶應義塾大学学術情報リポジトリ

Keio Associated Repository of Academic resouces

\begin{tabular}{|c|l|}
\hline Title & Colorectal Motility Induction by Sacral Nerve Electrostimulation in a Canine Model \\
\hline Sub Title & 仙骨神経電気刺激による結腸・直腸運動の誘発 \\
\hline Author & 平林, 健(Hirabayashi, Takeshi) \\
\hline Publisher & 慶應医学会 \\
\hline Publication year & 2006 \\
\hline Jtitle & 慶應医学 (Journal of the Keio Medical Society). Vol.83, No.2 (2006. 6),p.30- \\
\hline JaLC DOI & \\
\hline Abstract & \\
\hline Notes & 号外 \\
\hline Genre & Journal Article \\
\hline URL & $\begin{array}{l}\text { https://koara.lib.keio.ac.jp/xoonips/modules/xoonips/detail.php?koara_id=AN00069296-2006060 } \\
\text { 2-0030 }\end{array}$ \\
\hline
\end{tabular}

慶應義塾大学学術情報リポジトリ(KOARA)に掲載されているコンテンツの著作権は、それぞれの著作者、学会または出版社/発行者に帰属し、その権利は著作権法によって 保護されています。引用にあたっては、著作権法を遵守してご利用ください。

The copyrights of content available on the KeiO Associated Repository of Academic resources (KOARA) belong to the respective authors, academic societies, or publishers/issuers, and these rights are protected by the Japanese Copyright Act. When quoting the content, please follow the Japanese copyright act. 


\title{
Colorectal Motility Induction by Sacral Nerve Electrostimulation in a Canine Model
}

\author{
（仙骨神経電気刺激による結晹・直晹運仍の誘発）
}

\section{内容の要旨}

使排泄機梅ならぴにそれにおける仙肺神経系の役割の解明、およひ

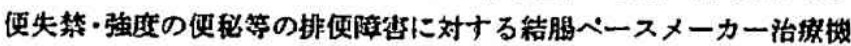
器について、䧽程成犬を用いて、検时を行なった。

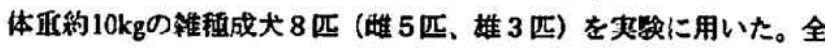
身麻酷下に、フォースストレイングージを、近位結胘、遥位結䏷、S状

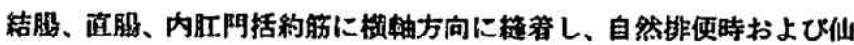

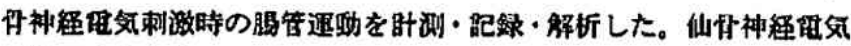
刺激は全身麻醉下に椎弓切除を加え、直梘下にて行った。

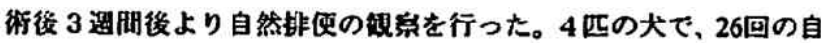

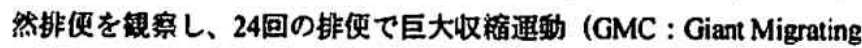
Contraction）の分析が可能であり、3 䄳類の特微的な通卯バターンが

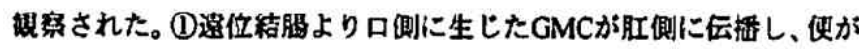

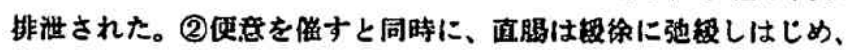

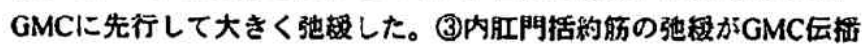
する間に踗められた。

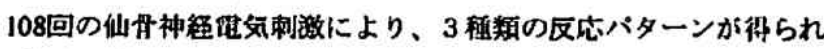

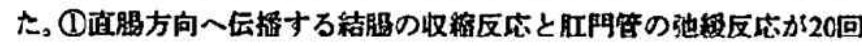

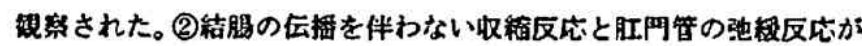

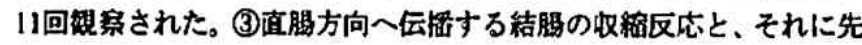

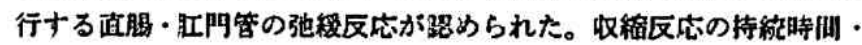

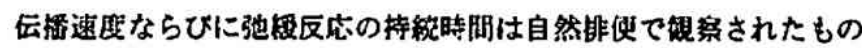

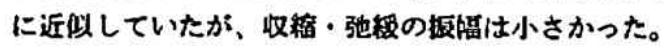

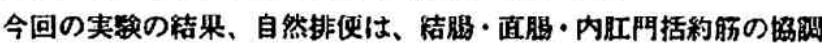

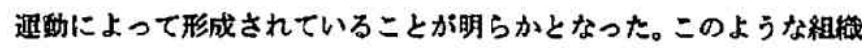
された消化管用動は胆管神経系によってプログラムされたものと推 察される。自然排使時の結胆・淔鸠・内肍門括約肠の遇物パターンと 類似した反応が仙神経跑気刺激によって再现された。以上から、自

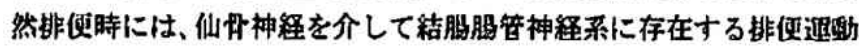
のフロログラムが起動されると考えられ、仙种程系は、自然排使にお

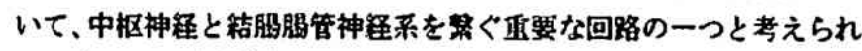
た。今回は、監床的な埋め込み实䮦ではなく、念性实駼であったが、 实際に排使が見られたこともあり、非使ペースメーカー作成の可能性 がより强く示晙された。

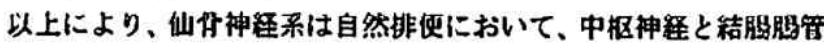
种程系を繁ぐ惩な回路の一つと考えられた。
健

\section{赤文籍疋の要旨}

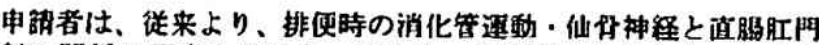

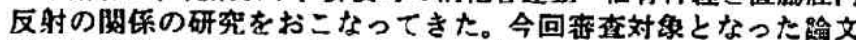
は、維租成犬を用いストレインダージトランステニーサー(以下

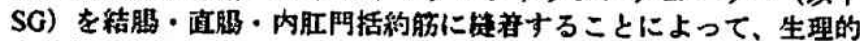

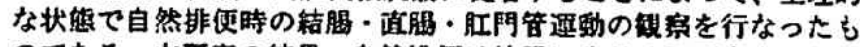
のてある。本研究の結果、自然非使は結渴に生しる肛門方向へ伝㩲 する巨大収程遇動（以下GMC）と、それに速動する直胆・肛門管の 驰极避的によって形成されることが明らかとなり、このような一巡 の消化管通㽖は胆管神释系によってフログラムされたものと推察さ

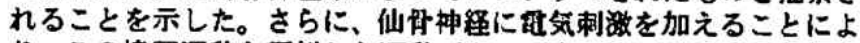

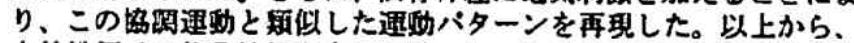
自然非使は、仙用神程を介して結腰胆管神释系に存在する非使通動 のプロクララが起動されることにより結渴・苗胆・肛門管の協㽗遇 邪が巷起され行なわれると考えられた。また、本研究に其つき便失

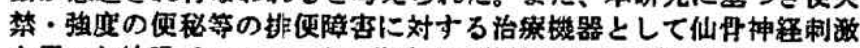
を用いた結渴ぺースメーカー作成の可能性が强く示吺された。

落花ではまず、排使時のGMCの開始部位について贸阔された。今

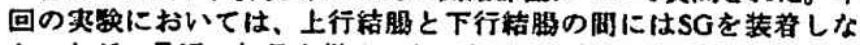

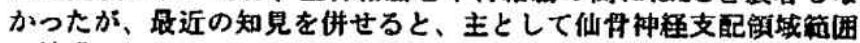

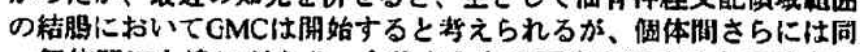
一㧽体閒にも遱いがあり、今後さらなる研究を要すると回答され

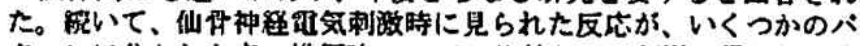
ターンに分かれた点、排使時のGMCに比校して、刺激でられた結

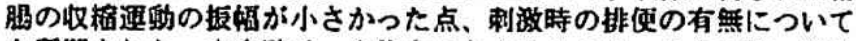
も婮間された。本実弱は、生体内でなされたため、全身麻醉、伴せ て結渴内容の有無にも影裂を受け、いくつかのバターンに分かれ、

振幅も小さかったと推测されると觯明し、実祭に排使も見られた例

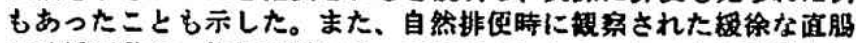

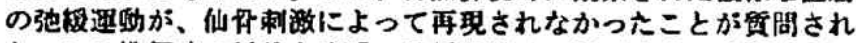

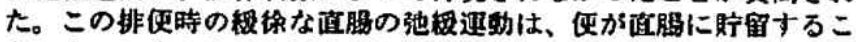
とによって生した受容性弛被と推察され、正渴照が伸辰され、その

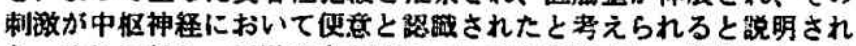
た。それに対し、刺激の求心路についても質間され、直渴からの自 律神㖓系の求心路に併せて、腹照なとからの体性神释からの求心路 も考えられると競明された。

続いて、本研究の臨床店用（結渴ペースメーカー作成の可能性）

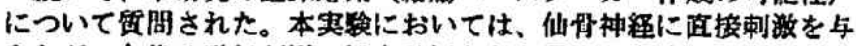

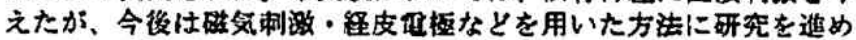

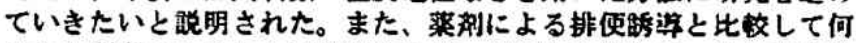

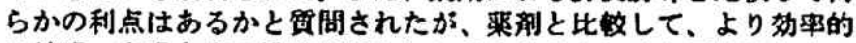
に結䏢・西渴内容の排泄が行なわれると考えられると回答された。 さらに、より奻果的に制激を加えるためには、㨁脇内容を計测する 必要があり、インピータンス等を用いた正渴容显测定器などの周边

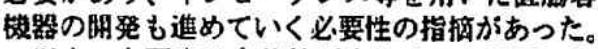

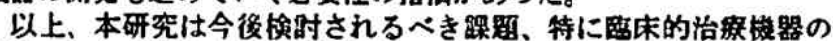

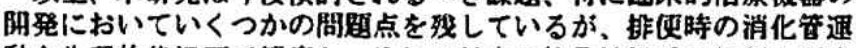

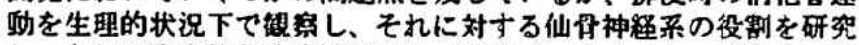

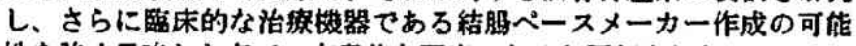

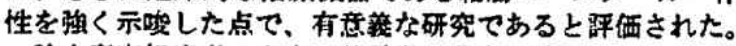

踰文策查担当者 主柆 外科学 北帛 政猢 内科学 旦比 紀文 生理学 抽的通介 解部学 相瞰 貝和

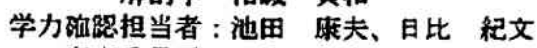
寉植委员是: 日比紀文 